\title{
Patrick Moore
}

Ex-Greenpeace activist turned biotech supporter believes that auditing the performance of biotech products is the only way to convince people of their value.

Nobody can say Patrick Moore doesn't have the courage of his convictions. When he was at Greenpeace, an organization he cofounded, he stood between seal pups and hammer-wielding thugs. Armed with no more than a life preserver, he steered a dingy in front of a harpoonmounted whaling ship. The self-described radical environmentalist even planted himself on rail tracks to stop trains carrying materials to nuclear power plants. Ironically, he now finds himself standing up to the forces he was instrumental in creating: Greenpeace and the environmental movement.

Moore abandoned Greenpeace in 1986 after growing frustrated by what he calls the infiltration into the movement of radicals bent on nothing short of ridding the world of capitalism and biotechnology. He now pursues his environmental agenda under the umbrella of his consultancy, Greenspirit.

As an environmental heretic, Moore took to op-eds and the environmentalist-bashing lecture circuit with the zeal of a recovering alcoholic preaching about demon rum. This reversal of allegiances has earned him high praise from the biotech community and the scorn of the environmental community, who see him as a traitor to the cause.

In a recent Wired article, Greenpeace director Paul Watson called Moore a "corporate whore...eco-Judas...lowlife bottom-sucking parasite, who has grown rich from sacrificing environmentalist principles for plain old money." To Moore, suffering personal insults like these is no more painful than getting arrested for trespassing and disturbing order during his Greenpeace days. "If personal insults are the price I have to pay, then so be it," he says.

"The [public and media] have bought into this idea biotech can't be trusted," Moore remarks, "I say it's the environmental groups who can't be trusted anymore and I can prove it." Moore's new crusadeone among many in his career-is precisely about giving legitimacy to biotech application $v i s$-à-vis environmental opponents. To do so, he suggests that an audit of the performance of biotech products is sorely needed to prove their strengths and weaknesses.

Indeed, he has come to realize that words only get a person so far. Instead, Moore says he will soon start creating public-private research collaborations with the expressed purpose of applying for research grants to analyze the risk-reward of biotech products. He maintains that this type of research is oddly, woefully incomplete. He has a point.

For example, he says he'd like to commission a study on the amount of $\beta$-carotene (the precursor to vitamin A) in transgenic 'Golden Rice' necessary to restore sight lost from vitamin A deficiency. Activists say people have to eat $9 \mathrm{~kg}$ of golden rice-Moore says $100 \mathrm{~g}$. Existing data are inconclusive. Yet, Daniel Sokol, an attorney with Steel Hector \& Davis, in Miami, Florida, who specializes in biotech trade issues, is among those who wish Moore Godspeed in his new odyssey. "By highlighting the importance of GMOs [genetically modified organisms] such as Golden Rice, Moore has presented the public and the environmental movement with the following question: if you have a cheap delivery method to prevent childhood blindness for a half million children a year, shouldn't you use it?"
Moore would like to go further and commission a study that would attempt to quantify the average increased yield, and average reduction in pesticide and herbicide use, from genetically modified crops like Bt (Bacillus thuringiensis) corn, cotton and soybeans. Activists say both figures are fraudulently inflated by biotech boosters. Moore says he's seen evidence that supports the boosters in his travels to farms throughout Asia and Africa. Again, there is no scientific consensus on this, either. Moore, however, believes that only hard data could prove him right as he feels that science is on his side. But unlike in his Greenpeace days, he now has more passionate supporters in the scientific community ready to lend their support to his cause.

One of those supporters is Martina Newell-McGloughlin, a US government consultant on GMO matters, and the well regarded director of the University of California's System-wide Biotechnology Program, which is based at the University of California, Davis. Like many, she sees Moore as a pragmatist rather than a turncoat. "Like a true scientist, Moore is willing to change his position when the preponderance of evidence or circumstance supports a different stand on the subject matter at hand," she says. "He is not an ideologue; he is a pragmatist with high ideals who knows what it takes to get results in the real world."

"The [public and
media] have bought
into this idea biotech
can't be trusted,"
Moore remarks, "I say
it's the environmental
groups who can't be
trusted anymore and I
can prove it."

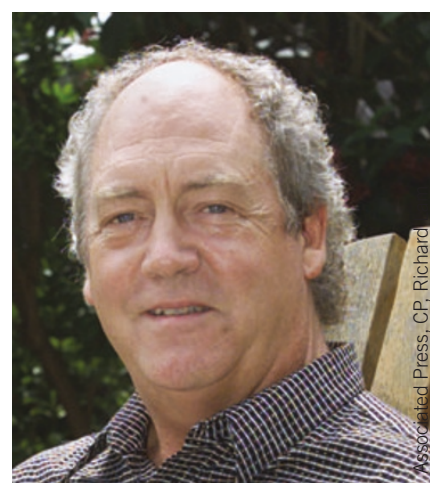

Maybe so, but it won't be easy to get government money to back what might be seen by some as politically motivated research objectives. And research financed by biotech companies won't be easy to sell unbiased. That leaves nonprofit groups like the Rockefeller Foundation that tend to look askance at grant seekers, like Greenspirit, with no track record. Then again, if anybody can find backing for a cause, it is surely Patrick Moore. He did, after all, help create and transform Greenpeace from a handful of staffers working in the basement of a church in Vancouver into a network of field offices in 22 countries with a $\$ 110$ million budget.

Christian Walter, a GM tree researcher at Forest Research in Rotorua, New Zealand, and a cofounder of (and exile from) the German arm of Greenpeace, says that Moore could be a bridge builder if only the environmental movement would let him. "Many will indeed be dismayed [with Moore's new mantra]," Walter says. "But, I believe the environmental movement needs to seriously rethink their stance on a number of issues (and genetic engineering in particular) and put them into perspective. They forget that nothing in this world is black or white, there are always shades of gray."

And, as Moore proves, shades of green.

Stephan Herrera, New York 